On Reputation: A Microfoundation of Contract Enforcement and Price Rigidity

Ernst Fehr, Martin Brown and Christian Zehnder

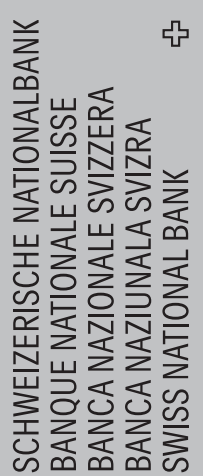


The views expressed in this paper are those of the author(s) and do not necessarily represent those of the Swiss National Bank. Working Papers describe research in progress. Their aim is to elicit comments and to further debate.

ISSN 1660-7716 (printed version)

ISSN 1660-7724 (online version)

๑ 2008 by Swiss National Bank, Börsenstrasse 15, P.0. Box, CH-8022 Zurich 


\title{
On Reputation
}

\section{A Microfoundation of Contract Enforcement and Price Rigidity}

\author{
Ernst Fehr ${ }^{1}$, Martin Brown ${ }^{2}$, Christian Zehnder ${ }^{3}$
}

July 2008

\begin{abstract}
We study the impact of reputational incentives in markets characterized by moral hazard problems. Social preferences have been shown to enhance contract enforcement in these markets, while at the same time generating considerable wage and price rigidity. Reputation powerfully amplifies the positive effects of social preferences on contract enforcement by increasing contract efficiency substantially. This effect is, however, associated with a considerable bilateralisation of market interactions, suggesting that it may aggravate price rigidities. Surprisingly, reputation in fact weakens the wage and price rigidities arising from social preferences. Thus, in markets characterized by moral hazard, reputational incentives unambiguously increase mutually beneficial exchanges, reduce rents, and render markets more responsive to supply and demand shocks.
\end{abstract}

JEL: D82, J3, J41, E24, C9

Keywords: Reputation, Reciprocity, Relational Contracts, Price Rigidity, Wage Rigidity

The views expressed in this paper are those of the authors and do not necessarily represent those of the Swiss National Bank.

This paper is part of the University Research Priority Program on the "Foundations of Human Social Behavior" which is financed by the University of Zürich.

Corresponding Author: Institute for Empirical Research in Economics, University of Zurich, Blumlisalpstrasse 10, CH-8006 Zurich, efehr@iew.uzh.ch.

${ }^{2}$ Swiss National Bank, Börsenstrasse 15, CH-8022 Zurich, martin.brown@snb.ch.

${ }^{3}$ Harvard Business School, Soldiers Field, Boston MA 02163, czehnder@hbs.edu. 
Severe moral hazard problems are pervasive in many labour, credit, and goods markets. Reputational incentives are likely to play an important role in such markets (MacLeod 2007) but empirical evidence on the role of reputation is still scarce. This paper empirically assesses the impact of reputational incentives on contract enforcement, the terms of trade, and the structure of interactions between contracting partners in a competitive environment with severe moral hazard problems. Our examination starts from a body of evidence indicating that heterogeneous preferences for fairness, equity, social image concerns, efficiency, or reciprocity generally have a non-negligible impact on behaviour in such environments. ${ }^{1}$ For convenience, we summarize these different non-pecuniary motives under the term "reciprocity" because these motives typically imply some kind of "reciprocal behaviour" in the principal-agent contexts we study. The evidence shows that reciprocity contributes to the enforcement of contracts in moral hazard situations but a considerable gap typically remains between the first best performance levels and the performance levels enforced by reciprocity. The efficiency enhancing effects of reciprocity on contract enforcement come at a cost, however - the payment of non-competitive rents to the agents and an extremely high degree of price stickiness in response to supply and demand shocks.

It is natural to ask how reputation formation affects the interactions between principals and agents because many relevant situations involve repeated interactions or situations where principals acquire information about agents' past behaviour. In fact, repeated interactions are ubiquitous in labour, credit, and goods markets. In view of the existence of a heterogeneous population of reciprocal and selfish individuals, reputational incentives inevitably interact with reciprocity in these environments. Therefore, focusing on the question how reciprocity and reputation interact in the enforcement of contracts is indispensable in understanding the impact of reputational incentives because reciprocal individuals' behaviour may generate strong reputation incentives for the selfish individuals to meet their contractual obligations.

Our main insights can be summarized as follows. Reputation formation strongly amplifies the positive effect of reciprocity on contract efficiency. The intuitive reason behind this finding is that the opportunity for reputation formation implies that selfish agents also have an incentive to behave as if they were reciprocal. By mimicking reciprocal behaviour, selfish agents make the principal believe that they are (at least potentially) reciprocal. Such a reputation is valuable for selfish agents because the principal only pays non-competitive rents

\footnotetext{
${ }^{1}$ The interested reader may consult reviews such as Fehr and Fischbacher (2002), chapter 3 of Camerer (2003) or the recent survey of Fehr, Goette and Zehnder (2008).
} 
to agents who have not yet been identified as selfish. As a consequence, reputational incentives imply that a relatively small fraction of reciprocal agents suffices to generate large efficiency gains. In fact, reputation effects can be sufficiently strong to sustain very high levels of efficiency, even when reciprocal behaviour alone cannot prevent a market collapse.

While reputation formation enhances efficiency, it also fundamentally alters the nature of interactions in competitive markets with moral hazard. The absence of third party enforcement of contracts give rise to a strong bilateralisation of trades, that is, a large share of all trades takes place in long-term relations between trading partners in which reciprocity and reputation sustain high performance levels. In fact, we can show that bilateral relations prevail even when public information about agents' past behaviour would provide adequate information for sustaining reputation incentives outside of such relations.

One might conjecture that the strong bilateralisation of market interactions could foster rent-sharing and the stickiness of prices with regard to supply and demand shocks because pairs of successfully cooperating traders might develop social ties that render fairness concerns more prominent. However, we find the opposite to be true. Reputational incentives lead to a substantial reduction in price stickiness relative to a situation in which only reciprocity can enforce contracts. This finding enables us to identify a main source for sticky prices, namely the absence of third party contract enforcement and the resulting reliance on reciprocity as a contact enforcement device. Reputational incentives mitigate this price stickiness, but they do not remove it completely: a substantial amount of price stickiness remains even in the presence of reputational incentives.

The remainder of the paper is structured as follows: Section 1 provides a short review of laboratory and field evidence on reciprocity as a contract enforcement device in one-shot interactions. Section 2 documents how reputation formation amplifies the positive impact of reciprocity on contract efficiency and how it affects market interactions in a thorough way. Section 3 provides new evidence indicating that reputation significantly mitigates the price rigidity that is generated by the absence of third party enforcement of contracts. Section 4 concludes the paper.

\section{Reciprocity, contract enforcement and price rigidity}

Recognizing how moral hazard problems affect the principals' and the agents' behaviour when neither explicit nor implicit (i.e., reputational) incentives are present is necessary for 
understanding the effects of reputation and how it interacts with reciprocity. Under these circumstances, reciprocity is the only remaining contract enforcement device. We thus provide a short review of the impact of reciprocity on contract enforcement and price rigidity, which sets the stage for studying the impact of reputation. ${ }^{2}$

A convenient tool for studying the impact of social preferences on contract enforcement and wage/price rigidity is the gift-exchange game (Fehr, Kirchsteiger and Riedl 1993). This game models a one-shot transaction in which explicit incentives are absent and the agent's performance (i.e. effort or product quality) is not legally enforceable. The most natural interpretations of this game are employment contracts in which the worker's effort is not contractible, or sales contracts for experience goods, when inspection cannot determine quality. The structure of the game is as follows: The principal suggests a contract to the agent, specifying a fixed payment and a requested performance level. While the payment to the agent is enforceable, the agent's performance is not. If the agent rejects the contract offer, he receives an outside option. If he accepts, he can choose his performance level independent of the requested level; higher performance generates higher revenues for the principal but also higher costs for the agent. The principal's profit is equal to the revenue generated by the agent's performance minus the fixed payment. The agent's payoff, in turn, is calculated as the fixed payment minus the cost of his performance. The parameters of the cost and revenue function are usually chosen in such a way that the efficient outcome is achieved when the agent chooses the maximum performance level.

If all players were purely self-interested, a very inefficient outcome would result in this game. Since higher levels of performance are associated with higher costs, selfish agents are never willing to provide more than the minimum performance level. Rational principals anticipate this behaviour and offer a payment that compensates the worker for his outsideoption and the cost of the minimum performance level. However, if there is a sufficiently large share of reciprocal agents who are willing to reward high fixed payments with high performance, it may be profitable for the principal to pay the agent a rent.

A large number of laboratory studies report evidence from one-shot gift-exchange experiments in which reputation formation cannot play a role (e.g., Fehr, Kirchsteiger and Riedl 1993; Fehr and Falk 1999; Gaechter and Falk 2002; Hannan, Kagel and Moser 2002; Charness 2004; Charness, Frechette and Kagel 2004; Brown, Falk and Fehr 2004; List 2006; Englmaier and Leider 2008). The results of these papers can be summarized as follows: A

\footnotetext{
${ }^{2}$ Readers familiar with this literature may skip this section.
} 
non-negligible share of agents chooses non-minimal performance levels when offered a payment that gives them a rent. Moreover, these reciprocal agents typically reward higher payments with higher performance. There are also many agents, however, who choose the minimal performance irrespective of the offered payment. On average, principals make payments that provide agents with a positive rent leading to wage rigidity relative to the competitive wage level. However, due to the substantial share of selfish agents, many principals refrain from payments high enough to induce maximum performance. As a consequence, average performance is usually significantly higher than the minimum, but still substantially lower than the efficient level. ${ }^{3}$

The gap between the efficient effort level and the actual effort provided in a simple gift exchange, in which only the agent can reciprocate, can be reduced if the principal is also given an opportunity to reciprocate (Fehr, Gaechter and Kirchsteiger 1997; Fehr, Klein and Schmidt 2007). For example, if the principal can reward or punish the agent ex post in a oneshot game, a significant increase in the effort level relative to the effort in a simple gift exchange can be achieved. This increase stems from the fact that reciprocal principals provide an incentive for selfish agents to provide non-minimal performance. However, even if the principal can reciprocate, the agents' average effort is typically still far from the first best level. ${ }^{4}$

While laboratory experiments have the great advantage of providing the researcher with a high degree of control, it is possible that findings identified in laboratory settings may not carry over to field environments. Fortunately, several researchers addressed this question with field experiments implementing gift exchange situations in natural environments. In order to study gift-exchange in the field, experimenters exogenously manipulated the fixed wage paid to workers in natural work environments with a one-shot character. The workers in these experiments perform tasks like data entry (Gneezy and List, 2006; Kube, Marechal and Puppe 2007; Englmaier and Leider, 2008), stuffing envelopes (Al-Ubaydli, Andersen, Gneezy and List 2007), newspaper promotion (Cohn, Fehr and Goette 2007) and planting trees (Bellemare and Shearer, 2007). In general, these studies confirm the existence of reciprocal responses in the field. If the wage is cut relative to the promised or expected payment, the

\footnotetext{
${ }^{3}$ An illustrative example is the one-shot condition in Brown, Falk and Fehr. (2004), where the performance levels could be chosen on a scale from 1 to 10 . While 10 would be the efficient level, the average performance ends up at a level of 3.3 .

${ }^{4}$ In Fehr, Klein and Schmidt (2007), for example, the principals have the option of paying a bonus ex post, that is, after observing the agents' effort. The first best effort level is 10 (on a scale from 1 to 10) but the agents' average effort is 5.2 .
} 
workers' output decreases substantially (Kube et al. 2007), indicating the relevance of negative reciprocity in the field. Positive effects of wage increases on workers' performance are also present in field settings. However, the average impact of a pure wage increase on effort has been small in several of the above mentioned studies (see Fehr, Goette and Zehnder 2008 for a more detailed discussion). One reason why in several field studies the effect of wage increases is small may be that the fairness increasing effect of a wage increase is not transparent: workers are simply paid a higher wage relative to what they were told when hired, but no explanation is given for the increase. ${ }^{5}$ The gift exchange hypothesis predicts that wage variations that are associated with fairness or kindness variations will lead to variations in performance; if wage variations do not affect workers' fairness or kindness perceptions, no performance effect is predicted. Support for this view comes from Cohn, Fehr and Goette (2007) and Kube, Marechal and Puppe (2008). Cohn et al. (2007) show that only those workers who view the previous wage as unfairly low respond significantly positive with their effort to a wage increase, while workers who perceived the previous wage as fair do not increase their effort level. Kube et al. (2008) show that workers who receive a non-monetary gift in gift wrap paper, which renders the kindness of the gift salient, exhibit a large effort increase, while a surprise wage increase by the amount of the value of the gift leads only to a small effort increase.

Taken together, the findings of laboratory and field experiments provide empirical support for the efficiency enhancing effect of reciprocity in situations of contractual incompleteness where principals face a moral hazard problem. However, in simple gift exchanges, in which only agents have a chance to reciprocate, the effects of monetary wage gifts on efficiency are not overwhelming. Moreover, this efficiency enhancing effect is associated with considerable wage rigidity, i.e., rent payments to the workers. The question then is how reputational incentives affect efficiency, prices, and trading patterns in an environment characterized by moral hazard that is already partially solved by reciprocal interactions between principals and agents.

\footnotetext{
${ }^{5}$ Therefore, employees may come up with many different interpretations for why they are paid more than expected. Some may believe that the employers' ability to pay is high enough. Others may believe that the initial wage promise was mistakenly low. Still others' may self-servingly attribute the wage increase as a reward for their ability. In all these cases, workers have no reason to believe that the wage increase constitutes a kind act and, therefore, the gift exchange hypothesis does not predict that effort should rise in these cases.
} 


\section{Reputation - a Powerful Amplifier of the Efficiency Enhancing Effect of Reciprocity}

In real-world markets with moral hazard, market participants often have the opportunity to transact repeatedly. If the same principals and agents interact repeatedly or if the principal has information about the agent's behaviour in previous transactions with other principals, the principal can condition the current contract terms on the agent's past behaviour. This may motivate the agent to perform, because if he satisfies the principal today, his future contract terms are more attractive. There is a large theoretical literature showing that these reputational forces may solve moral hazard problems even if all traders are completely selfish (see Klein Crawford and Alchian 1978 and Klein and Leffler 1981 for early discussions of this problem; later papers include Shapiro and Stiglitz 1984; Bull 1987; MacLeod and Malcomson 1989, 1998; Baker, Gibbons and Murphy 1994, 2002).

However, we already know from dozens of laboratory experiments and from the recent wave of field experiments that not all agents are selfish. Thus, an empirical assessment of reputation incentives must take possible interactions between reciprocity and reputation into account. One way to study these interactions is to implement laboratory games with a finite time horizon. In some cases, a finite time horizon is an empirically realistic approximation of real world phenomena. For example, there is a mandatory retirement age in many countries, making the end of one's employment relation is perfectly foreseeable. However, we use finitely repeated games in our context mainly as a work horse for studying interactions between reciprocal and selfish individuals because a commonly known final period enables us to identify the selfish individuals: selfish individuals will never provide non-minimal performance levels in the final period.

The seminal paper by Kreps, Milgrom, Roberts and Wilson (1982) shows that the mere belief in the existence of reciprocal players may sustain cooperative play for a large number of periods in a finitely repeated prisoners' dilemma game. Their argument begs the question where such a belief should come from. However, this becomes obvious in view of the strong evidence for the existence of reciprocal individuals. In the presence of reciprocal agents, selfish agents may have incentives to provide high performance if their principal treats them kindly. The reason is that such behaviour makes the principal believe that these agents are (at least potentially) reciprocal. Such a reputation is valuable for selfish agents because finite repetition implies that the principal only makes attractive offers to agents who have not yet been identified as selfish. This is due to the principal's anticipation that selfish agents will always shirk in the final period. By backward induction, this expectation unravels all 
incentives to make kind offers in any period of the interaction. The presence of a share of reciprocal agents may motivate the principal to make a generous offer to an agent of unknown type even in the last period. If principals are willing to make generous offers, this implies that workers can earn rents. However, selfish agents need to hide their type and imitate the behaviour of reciprocal agents in order to have access to these rents. Since not only the truly reciprocal agents, but the selfish ones as well, are willing to perform in response to generous offers in non-final periods, generous offers are then even more attractive to principals. In the following we show that reputational incentives indeed discipline the selfish types among the agents. Consequently, these incentives greatly increase the gains from trade and the frequency of trading between principals and agents in markets with moral hazard.

\subsection{Reputation in Relational Contracts}

Brown, Falk and Fehr (2004) examine gift-exchange in a laboratory market in which the parties can choose their trading partners. There are 7 principals and 10 agents. Each market participant can conclude a maximum of one contract per period so that there is an excess supply of agents. The matching between principals and agents takes place in a one-sided continuous posted-offer auction. Principals can make as many contract offers as they wish during a period, stipulating their payment and the desired performance. Moreover, principals can choose whether to make the contract offer public, in which case all market participants see the offer, and any agent can accept. Alternatively, a contract offer can be made privately to one agent, who is the only person who can see and accept the offer. After an agent has accepted a contract offer, he chooses his performance. The experiment lasts 15 periods, which is common knowledge among participants.

The main condition in this experiment is the incomplete contracts with fixed identities (ICF) treatment. In this treatment, contracts are not third-party enforceable, i.e. the agent can freely choose his performance, irrespective of the principal's requests in his contract offer. Also, all principals and agents have fixed identification numbers for the whole duration of the experiment. This feature enables principals and agents to engage in long-term relationships. Moreover, it allows principals within these relationships to condition their contract offers on the agent's past behaviour, so that reputation effects can emerge endogenously.

The authors compare the outcome of this main treatment to two control treatments. In the incomplete contracts with random identities (ICR) treatment, everything is identical to the 
ICF except that subjects' identification numbers are randomly reassigned in every period. Thus, reputation formation and relational contracting is ruled out in this treatment, and reciprocity is the sole contract enforcement device. The second control treatment is the complete contracts $(\mathrm{C})$ treatment in which contracts are third-party enforceable: agents must provide the performance desired by the principal in the accepted contract in this treatment and identification numbers of market participants are fixed throughout the experiment, so that long-term relationships are possible but not necessary to enforce performance.

Figure 1A shows that reputation opportunities cause a substantial increase in the average performance level. This effect is indicated by the large performance difference between the ICF and the ICR. In addition, the reputation effect is already significant in periods 1 and 2, consistent with the view that many subjects immediately understand the logic of reputational incentives. Figure 1B shows that reputational incentives indeed discipline selfish subjects. This figure shows each agent's average performance in periods 1-14 and in period 15. The selfish individuals chose the minimal performance of 1 in period 15, but many of them chose rather high performance levels in the non-final periods, indicating the disciplining effect of reputational incentives. In contrast, the reciprocal subjects also chose high performance levels in the final period. In fact, their final period performance was sufficiently high to render the payment of rents in this period profitable for the agents.

\section{Figure 1A and 1B here}

The principals disciplined the agents in the non-final periods by practicing a contingent renewal policy: If an agent provided high performance in period $t$, the principal offered him a new contract in $\mathrm{t}+1$. This contract was characterized by a high payment that implied a substantial rent for the agent. If an agent performed poorly, the principal offered him, with a very high probability, no contract at all in $\mathrm{t}+1$. In turn, many agents provided high performance as long as principals offered them contracts which involved substantial rents. The principals' contingent renewal policy led to a considerable bilateralisation of market interactions because the principals frequently made private offers to their incumbents. $44 \%$ of the offers in the ICF are private offers to the incumbent agent, while this only occurs in $10 \%$ of the cases in the $\mathrm{C}$ treatment, in which contract enforcement is exogenous. The differences in actual trades (accepted offers) are even more striking. 52\% of actual trades in the $I C F$ 
treatment are renewed contracts with the last-period agent. In contrast, only $8 \%$ of trades in the $\mathrm{C}$ treatment are contract renewals and $76 \%$ of the trades are initiated by public offers. Thus, the principals' contingent renewal policy in the ICF together with the associated performance increase led to long-term relations. Figure $1 \mathrm{C}$ documents this by showing the cumulative share of trades that took place in relationships of various lengths. For example, while $90 \%$ of all trades in the $\mathrm{C}$ treatment took place in one-shot or two-shot interactions, $51 \%$ of all trades in the ICF occurred in relationships that lasted 4 or more periods.

\subsection{Public Reputation in Relational Contracts}

The above evidence suggests that the provision of reputational incentives may fundamentally alter the nature of market interactions. If third parties enforce contracts, one-shot interactions prevail and incumbent workers receive no special treatment, whereas information about past behaviour becomes important if a moral hazard problem exists, thus transforming competitive markets into bilateral trading islands. There is indeed a considerable body of field evidence for the prevalence of repeated bilateral interactions in many markets. Important examples are long-term employment relationships (Hall 1982; Auer and Cazes, 2000), lending relationships between banks and small businesses (Berger and Udell 1995), long-term exchange relationships between providers and consumers of experience goods (Kollock 1994). Unfortunately, however, the field evidence does not reveal whether these repeated interactions emerge due to potential moral hazard and the provision of reputational incentives. The problem is that distinguishing reputational incentive effects from other reasons for repeated interaction, such as transaction costs of switching or insurance considerations (Azariadis 1975), is very difficult in the available field data. The laboratory experiments solve this problem, thus providing evidence that contracting problems cause repeated bilateral trading.

However, the bilateralisation of market interactions observed in Brown, Falk and Fehr (2004) may be a consequence of the fact that the agents could only acquire reputation in a bilateral interaction with a principal. Principals in this experiment only observed "their" agents' past performance, but not that of the other agents in the market, rendering the acquisition of a public reputation impossible. While public reputation plays little or no role at all in many labour and service markets, there are also markets where agents can acquire a public reputation. Public reputation mechanisms may be institutionalized - such as credit bureaus in credit markets - or they may arise informally - such as reference letters in the labour market. The question therefore arises whether the addition of public reputation 
removes or diminishes the bilateralisation of market interactions. Falk, Fehr and Zehnder (2004) addressed this question by adding a public reputation formation opportunity to the ICF treatment described above. All principals could observe all past wage and effort levels of all agents in the market in this modified ICF treatment. The authors observe that public reputation opportunities indeed reduce the bilateralisation of the market somewhat because the percentage of trades that takes place in long-term relations is significantly higher in the ICF than in the treatment with public reputation. However, public reputation has a surprisingly small effect because a large number of trades still take place in bilateral, longterm relations. This fact becomes transparent in Figure 1C if one compares the $\mathrm{C}$ treatment with the modified ICF treatment with public reputation. While roughly $40 \%$ of all trades in the public reputation treatment take place in relationships lasting 4 or more periods, almost all interactions in the $\mathrm{C}$ treatment occur in one or two-shot interactions. Thus, despite the fact that public reputation somewhat crowds out relational contracting, the principals still rely on contingent contract renewal of relational contracts as a discipline device to a large extent.

The addition of public reputation to the ICF also leads to an increase in performance, bringing it closer to its efficient level. In fact, the agents' average performance for an extended number of periods (period 7-13) is roughly 9 (on a scale between 1-10), only one unit below the efficient level. In particular, public reputation increases performance levels in case of lower wage offers, rendering the principal less dependent on reciprocity as a contract enforcement device. ${ }^{6}$

\subsection{Competition and Relational Contracts}

The threat of firing in case of low performance disciplines selfish agents in Brown, Falk and Fehr (2004); those who are fired face the risk of unemployment due to the excess supply of agents. What happens, however, if there is no risk of unemployment because there is an excess demand for agents? Are relational contracts that enforce high performance still possible in this environment, and if so, what are the terms of these contracts? In particular, how can selfish agents be disciplined if finding another principal who hires them is easy?

\footnotetext{
${ }^{6}$ Brown and Zehnder (2007) examine the impact of institutionalised information sharing between lenders on the behaviour of borrowers in the credit market. They find that in the absence of the possibility for repeated interaction, information sharing between lenders generates substantial reputation incentives for selfish borrowers to repay loans. When relationship formation is possible, they confirm the findings of Brown, Falk and Fehr (2004) and Falk, Fehr and Zehnder (2004). Bilateral relationships themselves motivate repayment, so that information sharing has little additional impact on borrower behaviour. Public information sharing also slightly reduces the formation of bilateral long-term relationships.
} 
Models of labour and credit markets (Carmichael, 1984, MacLeod and Malcomson 1998, Boot and Thakor 1994) show that relational contracts can, in principle, sustain high performance by agents even when these are in high demand. In order to do so, however, incumbent principals must offer contracts which involve quasi-rents for agents: Once the agents are in a relationship with a principal, the future value of this relationship must be higher than potential value of switching to an "outside" principal.

In a recent paper, Brown, Falk and Fehr (2008) examine the principals' performance enforcement strategies when there is strong competition for agents' services. They modify their experiment from 2004 by implementing an excess demand for agents (10 principals and 7 agents). In the following we call this the high-demand market, and refer to their 2004 experiment as the low-demand market. The results of Brown et al. (2008) show that principals' contract offers also provide reputational incentives for selfish players when there is an excess demand for agents. Those agents who provide high effort receive a wage offer in the next period from their incumbant principal which exceeds the wages they could get from outside principals in the market. In this way, principals in the high-demand market reward high performance. As a result, the agents' mean performance in the ICF treatment is significantly higher than in the ICR treatment of the high-demand market (see Figure 2).

However, the excess demand for agents leads to a lower incidence of long-term relations. For example, relationships exceeding 6 periods are substantially less frequent in the market with high-demand ( $24 \%$ of all trades) than in the market with low-demand $(45 \%$ of all trades). This suggests that strong competition for agents makes sustaining long-term relations more difficult, as agents are more likely to abandon their incumbent principal. This conjecture is confirmed by comparing the break-up of relationships in the ICF treatment under both market conditions. In the market with a high-demand, principals are equally likely to make a renewed contract offer to their last-period agent as in the market with an excess supply of agents $(80 \%)$. However, while agents only reject $2 \%$ of these offers in the market with lowdemand, $28 \%$ were rejected in the market with high-demand.

\section{Insert Figure 2 here}

Does the lower frequency of long-term relations in the market with high-demand reduce agents' performance relative to the market with low-demand? Surprisingly, it does not. The 
agents' mean performance by period evolves almost identically under both market conditions (compare ICF high with ICF low in Figure 2), causing almost the same average performance under high-demand (6.7) as under low-demand (6.9). The identical performance in the two conditions, despite a lower incidence of long-term relations in the high-demand condition, is somewhat puzzling. There are two explanations for this finding: First, due to stronger competition for agents, wages are substantially higher under high-demand than under lowdemand which induces higher performance by reciprocal agents (see section 3 for a detailed discussion of wages in the high-demand and low-demand conditions). Thus in the market with high-demand, reciprocity in combination with higher wages may play a larger role in performance provision. Support for the larger role of reciprocity under high-demand is provided in Figure 2, which shows that mean performance is substantially higher in the highdemand condition of the ICR than in the low-demand condition of the ICR. Second, the authors find that in the high-demand market reputational incentives are still strong in many relationships which break off early. As discussed above, many relationships in the high demand market are broken off by the agents after they have performed well and received a renewed contract offer. This suggests that agents provide a high level of effort for their current principal because the expected payments from "outside" principals are lower than those of their current one. However, once in a while though, outside principals make high wage offers which lure agents away from their current relationship. Indeed, the authors find that in the majority of cases (74\%) in which relationships are broken off by the agent, the agent had received an outside offer which was at least as high as that of his current principal. Since agents sometimes terminate ongoing high performance relations after the arrival of a high outside offer in the high-demand treatment, average performance in short and medium term relations is substantially higher than in the low demand treatment where relationships are mostly broken off by unsatisfied principals

\subsection{Reputation Effects when Reciprocity Alone Fails}

In the previous subsections, we reported evidence showing that reputation formation opportunities amplify the impact of reciprocity and substantially increase agents' performance levels. However, two important features facilitate contract enforcement in the previously reported experiments. First, the parameters of the experiments were chosen in such a way that the typically prevailing share of reciprocal subjects (40-60\%) renders trading in a one-shot environment viable. Thus, almost all feasible trades took place even in the absence of any 
reputational incentives, i.e., non-minimal performance levels could be attributed to reciprocity alone. This raises the question of the effects of reputational incentives when reciprocity alone is too weak to maintain trading. Second, the principals in the previous subsections had perfect information about the incumbent agents' past effort in the relationship. Thus, if an agent provided low effort, there was no ambiguity in interpreting this event: the agent did not want to provide a higher effort, providing a good signal about the agents' type. However, random exogenous events may, in reality, be responsible for a low output. If the principal can only directly observe an agent's output, but not his effort per se, a low output ceases to be a precise indicator of low effort. A low output may then indicate bad luck or a low effort; this ambiguity may mitigate the power of contingent renewal policies because future rewards can only be made contingent on a random output measure.

In theory, reputational equilibria with high performance can also be sustained if principals cannot observe the agent's effort perfectly and reciprocity alone fails to enable trade (e.g., Kreps and Wilson 1982; Kreps, Milgrom, Roberts and Wilson 1982; Camerer and Weigelt 1988; Diamond 1989, Brown and Zehnder 2007, Fehr and Zehnder 2008). However, little is known empirically about the impact of reputational incentives on contract offers and trading frequency in such a "hostile" environment. For this reason Fehr and Zehnder (2008) conducted a credit market experiment which implements both features mentioned above. Two sources of moral hazard coexist in their credit market. First, the lender cannot observe the borrower's project choice and, therefore, borrowers may choose inefficient high risk projects. Second, the absence of legal enforcement of repayments implies that borrowers may withhold their repayment even if they successfully realized their projects.

The experimental credit market consists of 17 participants. Seven participants are lenders, the other ten are borrowers. Each borrower can realize one of two projects in each of the 20 periods: an efficient low-risk project or an inefficient high-risk project. Borrowers have no equity and need external funding from a lender to realize a project. Lenders can make as many contract offers as they wish in a one-sided continuous posted-offer auction. While the loan size is exogenously fixed, a contract offer determines the desired project and a desired repayment in case of project success. Contract offers can be public (every borrower can accept) or private (only a specific borrower can accept). Each lender and each borrower can conclude a maximum of one contract per period. Borrowers who have obtained credit can realize either the inefficient high risk project or the efficient low risk project; a random device determines whether the project is a success or a failure. Both the project choice and the 
realized project return are private information to the borrower. In case of a project failure, the project's return is zero and the borrower cannot make a repayment. If the project turns out to be successful, the borrower is able the make a repayment up to the level of the project return.

In the main treatment of Fehr and Zehnder (2008), lenders and borrowers have fixed identification numbers, enabling lenders to establish long-term relationships with specific borrowers if they want to. Since this treatment is similar to the treatments with incomplete contracts and fixed identities in Brown, Falk and Fehr $(2004,2008)$ we also label it ICF. In the control treatment intentionally repeated interactions are excluded by randomly reassigning ID numbers at the beginning of every period - accordingly we call this treatment ICR.

The more realistic setup with stochastic outcomes and asymmetric information makes reputation formation in the ICF treatment of this experiment much more difficult than in the experiments reported above. Since lenders can neither observe the project choice nor its outcome, they do not know whether a defaulting borrower is unable (because the project failed) or unwilling to repay his credit. Even an honest borrower who intends to repay and who chooses the efficient, low-risk project may face a project failure, making him unable to repay his debt. The lender can therefore never know with certainty whether he faced an opportunistic borrower who did not intend to repay his debt or whether the borrower had just bad luck.

\section{Figure 3 here}

The experimental results indicate that individual reputation formation in long-term relations is still a powerful contract enforcement device even if the informational conditions make acquiring a good reputation very difficult. The lack of repayment incentives leads to a breakdown of trading in the credit market in the ICR, where reputation formation opportunities are absent. Although a considerable fraction of reciprocal borrowers repay credits, trading is, on average, not profitable for lenders. Figure 3 shows the realized fraction of available contracts over time. While almost all lenders enter the credit market in the beginning, there is already a sharp decline in market trading in period 4 in the ICR. After period 4, trading gradually decreases until the frequency of market trading becomes very low. In the final period, only $17 \%$ of the feasible contracts are concluded. In contrast, a stable credit market emerges in the ICF where reputation formation is possible and borrowers can 
acquire a reputation. Figure 3 indicates that at least 74 percent of the available trades take place in each of the first 19 periods. Overall, 81 percent of the available contracts are concluded. In this treatment, lenders establish long-term relations and condition future credit offers on the borrower's current repayment behaviour so that the borrowers face incentives to choose the efficient low-risk project and to repay their debt. As in Brown, Falk and Fehr (2004), this leads to a bilateralisation of the market: the majority of trades are concluded by pairs who interact at least five times with each other. Thus, reputation formation in endogenously formed long-term credit relations strongly alleviates the double moral hazard problem in the credit market and allows for mutually beneficial trades between lenders and borrowers.

\section{The Impact of Reputational Incentives on Price Rigidity}

A considerable body of evidence indicates that prices in goods markets (Blinder 1991; Cechetti 1986; Carlton 1986), credit markets (Hannan and Berger 1991; Neumark and Sharpe 1992), and particularly in labour markets are rigid (Blinder and Choi 1990; Akerlof, Dickens and Perry 1996; Altonji and Devereux 2000; Smith 2000; Nickell and Quintini 2003; Fehr and Goette 2005, Dickens et al. 2007). While there are many different explanations for price and wage rigidity in the literature, such as risk aversion (Azariadis 1975), transaction costs (Mankiw 1985, Salop 1979), or imperfect information (Lucas 1972), reciprocity has been suggested as one important source of rigidity in markets characterized by moral hazard (Akerlof and Yellen 1990). The evidence from competitive gift exchange markets discussed in Section 1 confirms that subjects in the role of employees are typically paid substantially more than their reservation wages, implying that wage levels do not converge to competitive levels. In addition to the level rigidity of prices and wages identified in those papers, there is also another interesting type of rigidity. This second type of rigidity concerns the question of how wages and prices change if shocks to supply and demand occur. Brandts and Charness (2004) nicely show that such shocks exert little influence on prices in gift exchange markets. They did not implement a control treatment with legal contract enforcement, however. Therefore, they cannot identify the source of the observed price rigidity, that is, whether the enforcement of contracts through reciprocity causes the low response of prices to shocks.

Does relational contracting, i.e. the provision of reputation incentives in bilateral repeated trades, strengthen or weaken wage and price rigidity? Repeated game models of labour markets (Shapiro and Stiglitz 1984, MacLeod and Malcolmson 1989 and 1998) show 
that relational contracting may lead to the payment of non-competitive rents in bilateral relationships. However, these models of relational contracting exhibit multiple equilibria which makes it impossible to predict how high these rents will be. Thus theory cannot tell us whether rents paid in relationships will be higher or lower than those which would prevail if repeated interaction were not feasible, and reciprocity alone would drive contract enforcement. The multiplicity of equilibria also makes it impossible to predict how market interactions and prices respond to exogenous shocks because for any set of exogenous parameters there exist many different equilibria with different behaviours and prices.

The data in Brown Falk and Fehr $(2004,2008)$ enable us to answer the above questions on the role of reputational incentives in price rigidity. Their data allows us to study prices when reputation and reciprocity affect market outcome (ICF treatment), and compare these to prices when reciprocity alone affects the outcome (ICR treatment) or when contracts are third-party enforced ( $C$ treatment $)$. Moreover, we can study price variation across market conditions in each of these treatments by comparing prices under high-demand (10 principals and 7 agents) and low-demand (7 principals and 10 agents).

As we showed above, mean performance levels differ strongly across these treatments. When we compare prices, and price rigidity, across treatments it is therefore important to account for different performance levels. What we are interested in, after all, is how much a principal must pay for a given (or expected) performance level. In the following we therefore compare prices paid for a given performance level. ${ }^{7}$ Figure 4 displays the mean prices paid for performance levels $6-10$ in each treatment. ${ }^{8}$

\section{Figure 4 here}

The figure shows that prices respond strongly to supply and demand changes under third party enforcement ( $\mathrm{C}$ treatments). At all performance levels prices are much higher in the high demand condition and at the most frequent performance level of 10 the price in the high

\footnotetext{
${ }^{7}$ In the ICF and ICR treatments the principals were asked, after a contract was accepted, which effort level they expected from the agent. We replicated our analysis of price rigidity in Figure 4 and Table 1 controlling for this "expected" performance rather than actual performance and observed qualitatively identical results. This is not surprising because actual performance levels and expected performance levels are highly correlated.

${ }^{8}$ There are almost no observations at performance levels below 6 in the $\mathrm{C}$ treatment, making a reliable comparison with the other treatments at these performance levels impossible. In the ICR treatment there are sufficient observations at each effort level from 6 to 10 to allow a reliable comparison with the ICF and C treatments.
} 
demand condition is more than 40 units higher than in the low demand condition. This large amount of price flexibility stands in sharp contrast to the ICR treatment, where only reciprocity can be used to enforce contracts. Prices are much less responsive to changes in supply and demand in the ICR, indicating a remarkable degree of price stickiness in this environment and corroborating the results in Brandts and Charness (2004). Moreover, almost all interactions are one-shot in the $\mathrm{C}$ treatments and all interactions are one-shot by design in the ICR treatment. Therefore, the difference between the $\mathrm{C}$ and the ICR treatment cannot be due to differences in the duration of interactions within pairs but must, instead, be due to the absence of third party enforcement and the resulting reliance on reciprocity as a contract enforcement device.

How does the introduction of reputational incentives in an environment without third party enforcement and explicit incentives change the responsiveness of prices to shocks? Figure 4 shows that reputational incentives increase the flexibility of prices considerably compared to the near absence of flexibility in the ICR condition. The formal tests reported in column 1 of Table 1 also support this result. The OLS regression shows that the price difference between excess demand and excess supply is roughly 10 units lower in the ICR treatment than in the ICF treatment. However, Figure 4 and Table 1 also show that reputational incentives do not completely restore price flexibility because price differences between high and low demand condition are roughly 13 units larger in the $C$ treatment than in the ICF treatment.

\section{Table 1 here}

Why do reputational incentives alleviate price stickiness? Reputation incentives may weaken downward price rigidity because they partially disburden prices from their function of motivating agents. Generous fixed payments are the only way to induce (reciprocal) agents to provide non-minimal performance in a one-shot gift exchange environment. In a setting with repeated interactions, selfish (and reciprocal) agents are concerned about the consequences of their current behaviour for their future earnings. In this environment, it is possible to motivate the performance of selfish (and reciprocal) agents with less generous fixed payments. Figure 4 informs us about how the downward rigidity of prices is influenced by reputation incentives. The prices in the $\mathrm{C}$ condition provide us with information about what prices the principals 
have to pay under competitive conditions with third party enforcement of contracts. Thus, by comparing prices in the $\mathrm{C}$ condition with those in the ICF and the ICR conditions, we can compute the rents paid in the latter two conditions. The agents in the ICR earn a considerable rent when there is a low demand for them. They receive prices that are roughly 17 units higher in the ICR than in the $\mathrm{C}$ treatment - a difference that is highly significant according to column 2 in Table 1. Prices are lower at any given performance level in the ICF treatment than in the ICR treatment. However, this price difference is small and insignificant (see ICR coefficient in column 2 of Table 1).

Reputation incentives may also affect upward price rigidity in markets characterized by moral hazard problems. If principals in a one-shot situation expect that only some agents behave reciprocally, the expected performance of agents is lower for any price offer compared to a situation in which contracts are enforceable. Therefore, the principals in the ICR will offer lower prices for any desired effort level compared to principals in the $\mathrm{C}$ treatment, i.e., the lower performance expectation in the ICR constrains the impact of competition for agents on agents' wages. In the ICF reputation incentives increase the expected performance relative to the ICR, and thus allow principals to compete more vigorously for agents by offering higher prices. However, as reputation incentives do not lead to perfect contract enforcement, the expected performance in the ICF is still lower than in the $\mathrm{C}$ treatment for any desired performance level. As a consequence, firms in the ICF are less willing to bid up prices in the high demand condition, implying a certain amount of upwards price rigidity relative to the $\mathrm{C}$ treatment. Figure 4 and column 3 of Table 1 document the upwards rigidity of prices in the high demand condition: In the ICF and ICR conditions wages are significantly lower than in $\mathrm{C}$ condition. In addition, prices in the ICF are significantly higher than in the ICR for each effort level.

Comparing the first three columns of Table 1 there seems to be an interesting asymmetry in the effect of reputational incentives on price rigidity: In the high demand condition prices in the ICF are substantially and significantly higher than in the ICR while in the low demand condition prices in the ICF are almost identical to those in the ICR. Indeed, the coefficients of $I C R$ in these columns suggest that the lower price responsiveness across demand conditions in the ICR compared to the ICF (9.7 points, see column 1) is mainly driven by a reduced upward price rigidity in the high demand condition of the ICF ( 8.4 points, see column 3). This finding is confirmed in a pooled analysis of all six treatments reported in the final column of the table. In this regression, the ICF condition of the low demand 
condition is the omitted category. Therefore, the ICR term captures the difference in prices between the ICR and ICF treatments for the low demand condition, which is identical to the corresponding coefficient in regression (2). As this coefficient is close to zero and insignificant we can conclude that the ICF does not alleviate downwards wage rigidity in the low demand condition. The coefficient for High demand measures the price increase in the ICF treatment relative to the low demand condition. The negative interaction term ICR* High demand indicates that the impact of the high demand condition (relative to the low demand condition) is significantly lower in the ICR relative to the ICF condition, i.e., the high demand condition raises prices considerably less in the ICR. This result suggests that the increased responsiveness of prices to demand shocks in the ICF (relative to the ICR) is mainly due to the higher average performance under reputational incentives which enables the principals to compete more strongly for scarce agents by offering them higher wages.

\section{Summary and Conclusions}

We examined the impact of reputational incentives on contract enforcement, the terms of trade and trading patterns in competitive markets with moral hazard. The evidence indicates that reputation formation strongly amplifies the positive effect of reciprocity on contract efficiency. The opportunity for reputation formation gives selfish agents an incentive to mimic the reciprocal agents' behaviour in order to improve the future contract offers they may receive from principals. As a consequence, reputation effects can be sufficiently strong to sustain high levels of efficiency, even when reciprocal behaviour alone cannot prevent a collapse of market trading. While reputation formation does enhance efficiency, it also fundamentally alters the nature of market interaction. Long-term trading in bilateral pairs replaces one-shot interactions when third party enforcement of contracts is absent and reputation is a key force of enforcing contracts. In fact, bilateral relations play an important role in our experimental markets even if a public reputation can be acquired.

Interestingly, we find that the bilateralisation of the market through relational contracting increases the responsiveness of prices to changes in supply and demand. We are able to identify the absence of third party enforcement and the subsequent reliance on reciprocity as an enforcement device as the key force behind the unresponsiveness of prices to shocks. Relational contracting increases price flexibility by rendering the principals more willing to compete for scarce agents, that is, by alleviation upwards price rigidity. In addition, 
it also alleviates downwards price rigidity somewhat but this effect is small and not significant.

Our findings are a first step in understanding the relevance of relational contracts for price formation in labour, goods and credit markets. Future studies should disentangle the impact of contract enforcement problems on price rigidity from the role of alternative causes such as transaction costs, insurance considerations, imperfect information or imperfect competition. Moreover, field studies should examine whether the observed impact of moral hazard on wage rigidity in the labour market, is comparable to its impact on prices in goods markets and interest rates in credit markets. Understanding whether the rigidity of prices and interest rates are driven by imperfect competition or transaction costs, or are the result of inherent contract enforcement problems is not only of academic interest, but also of key importance to policy makers in central banks and to competition authorities. 


\section{References}

Akerlof, G.A., W.T. Dickens, and G. L. Perry (1996). "The Macroeconomics of Low Inflation", Brookings Papers on Economic Activity 1, 1-75.

Akerlof, G.A. and J.L. Yellen (1990): "The Fair Wage-Effort Hypothesis and Unemployment", Quarterly Journal of Economics, 105, 2, 255-283.

Altonji, J.G., and P.J. Devereux (2000). "The Extent and Consequences of Downward Nominal Wage Rigidity", In S. Polachek (ed.). Worker Well-Being, \# 7236, Elsevier.

Al-Ubaydli, O., S. Andersen, U. Gneezy, and J. A. List (2006): "For love or money? Testing non-pecuniary and pecuniary incentive schemes in a field experiment", Working paper.

Auer P. and S. Cazes (2000): "The Resilience of the Long-Term Employment Relationship: Evidence from Industrialized Countries", International Labour Review, 139, 4, 379-408.

Azariadis C. (1975): "Implicit Contracts and Underemployment Equilibria", Journal of Political Economy, 83, 1183-1202.

Baker, G., Gibbons, R., and Murphy, K.J. (1994): "Subjective Performance Measures in Optimal Incentive Contracts.” Quarterly Journal of Economics 109:1125-56.

Baker, G., R. Gibbons and K.J. Murphy (2002): "Relational Contracts and the Theory of the Firm", Quarterly Journal of Economics, 109, 1125-56.

Bellemare, C. and B. Shearer (2007): "Gift exchange within a firm: Evidence from a field experiment", CIRP'EE Working Paper 07-08.

Blinder A. S. (1991): "Why are Prices Sticky) Preliminary Results from an Interview Study", American Economic Review 81, 89-96.

Berger A., and G.F. Udell (1995): "Relationship Lending and Lines of Credit in Small Business Finance", Journal of Business, 68, 351-381.

Blinder A. S. and D. Choi D (1990): "A Shred of Evidence on Theories of Wage Stickiness", The Quarterly Journal of Economics, 105, 4, 1003-1015.

Boot, A.W.A, and A.V. Thakor (1994): "Moral Hazard and Secured Lending in an Infinitely Repeated Credit Market Game", International Economic Review, 35, 4, 899-920.

Brandts J. and G. Charness (2004): "Do Labour Market Conditions Affect Gift Exchange? Some Experimental Evidence", Economic Journal, 114, 684-708.

Brown, M., A. Falk and E. Fehr (2004): "Relational Contracts and the Nature of Market Interactions", Econometrica, 72, 4, 747-780.

Brown, M., A. Falk and E. Fehr (2008): "Competition and Relational Contracts: The Role of Unemployment as a Disciplinary Device", IZA Discussion Paper 3345. 
Brown, M. and C. Zehnder (2007): "Credit Reporting, Relationship Banking, and Loan Repayment", Journal of Money Credit and Banking, 39, 1883-1918.

Bull, C., (1987): "The Existence of Self-Enforcing Implicit Contracts", Quarterly Journal of Economics, 102, 147-159.

Camerer C. F. (2003): Behavioral Game Theory: Experiments in Strategic Interaction, Princeton, Princeton University Press.

Camerer C. F. and K. Weigelt (1988): "Experimental Tests of a Sequential Equilibrium Reputation Model", Econometrica, 56, 1-36.

Carlton D. W. (1986): "The Rigidity of Prices", American Economic Review, 76, 637-658.

Carmichael, L. (1984): "Can Unemployment be Involuntary?: Comment", American Economic Review, 75, 5, 1213-1214.

Cecchetti S. G. (1986): "The Frequency of Price Adjustments: A Study of Newsstand Prices of Magazines", Journal of Econometrics, 31, 255-274.

Charness, G. (2004): "Attribution and Reciprocity in an Experimental Labour Market, Journal of Labour Economics, 22, 553-584.

Charness, G., G. Frechette, and J. Kagel (2004): "How Robust is Laboratory GiftExchange", Experimental Economics, 7, 189-204.

Cohn, A., E. Fehr, and L. Goette (2007): "Gift exchange and effort: Evidence from a field experiment", Manuscript, University of Zurich.

Diamond, D. W. (1989): "Reputation Acquisition in Debt Markets", The Journal of Political Economy, 97, 4, 828-862.

Dickens, W. T., L. Goette, E.L. Groshen, S. Holden, J. Messina, M.E. Schweitzer, J. Turunen and M.E. Ward (2007): "How wages change: Micro evidence from the international wage flexibility project", The Journal of Economic Perspectives 21, 2, 195-214.

Englmaier F. and S. Leider: (2008) "Contractual and Organizational Structure with Reciprocal Agents", mimeo, Harvard Business School.

Falk A., E. Fehr and C. Zehnder (2004): „Reputation and Performance“, mimeo, University of Zurich.

Fehr E. and A. Falk (1999): "Wage Rigidity in a Competitive Incomplete Contract Market", Journal of Political Economy, 107, 1, 106-134.

Fehr E. and U. Fischbacher (2002): "Why Social Preferences Matter - The Impact of Nonselfish Motives on Competition, Cooperation, and Incentives", Economic Journal, 112, C1-C33. 
Fehr E., S. Gachter and G. Kirchsteiger (1997): "Reciprocity as a Contract Enforcement Device: Experimental Evidence," Econometrica, 65, 833-860.

Fehr, E. and L. Goette (2005) "Robustness and real consequences of nominal wage rigidity", Journal of Monetary Economics 52, 4, 779-804.

Fehr E., L. Goette and C. Zehnder (2008): "The Behavioral Economics of the Labor Market: Central Findings and their Policy Implications", Working Paper, Federal Reserve Bank of Boston.

Fehr E., G. Kirchsteiger, and A. Riedl (1993): "Does Fairness Prevent Market Clearing? An Experimental Investigation", Quarterly Journal of Economics, 108, 437-460.

Fehr E., A. Klein, and K. M. Schmidt (2007): "Fairness and Contract Design" Econometrica 75, 121-154.

Fehr E. and C. Zehnder (2008): "Reputation and Credit Market Formation", Working Paper, University of Zurich.

Gaechter S., and A. Falk (2002): "Reputation and Reciprocity: Consequences for the Labour Relation", Scandinavian Journal of Economics, 104, 1-26.

Gneezy, U. and J.A. List (2006): "Putting behavioral economics to work: Field evidence of gift exchange", Econometrica 74(5), 1365-1384.

Hall R.E. (1982): "The Importance of Lifetime Jobs in the U.S. Economy", American Economic Review, 72, 4, 716-724.

Hannan, T.H. and A.N. Berger (1991): "The Rigidity of Prices: Evidence from the banking industry", American Economic Review, 81, 938-945.

Hannan, L., J. Kagel, and D. Moser (2002): "Partial Gift Exchange in Experimental Labour Markets: Impact of Subject Population Differences, Productivity Differences, and Effort Request on Behaviour", Journal of Labour Economics, 20, 923-951.

Klein, B., Crawford, R., and Alchian, A. (1978): "Vertical Integration, Appropriable Rents and the Competitive Contracting Process." Journal of Law and Economics 21:297-326.

Klein, B. and Leffler, K.B (1981): "The Role of Market Forces in Assuring Contractual Performance," Journal of Political Economy 89(4), 615-41.

Kollock, P. (1994): "The Emergence of Exchange Structures: An Experimental Study of Uncertainty, Commitment, and Trust". American Journal of Sociology, 100, 313-345.

Kreps, D., P. Milgrom, J. Roberts and R. Wilson (1982): "Rational Cooperation in the Finitely Repeated Prisoners' Dilemma", Journal of Economic Theory 27, 2, 245-252.

Kreps, D., and R. Wilson (1982): "Reputation and Imperfect Information", Journal of Economic Theory 27, 2, 253-279. 
Kube, S., M.A. Maréchal, and C. Puppe (2006): "Putting reciprocity to work- positive versus negative responses in the field", University of St. Gallen Discussion Paper no. 200627.

List, J. A. (2006): "The behavioralist meets the market: Measuring social preferences and reputation effects in actual transactions", Journal of Political Economy 114(1), 1-37.

Lucas R. E. Jr. (1972): "Expectations and the Neutrality of Money", Journal of Economic Theory, 4, 103-124.

MacLeod, W. B. \& J. M. Malcolmson (1989): "Implicit Contracts, Incentive Compatibility, and Involuntary Unemployment", Econometrica, 57, 2, 447-480.

MacLeod, W. B. \& J. M. Malcolmson (1998): "Motivation and Markets", American Economic Review, 88, 388-411.

MacLeod, W. B. (2007): „Reputations, Relationships and the Enforcement of Incomplete Contracts“, Journal of Economic Literature 45, 2, 595-628.

Mankiw, G. (1985): "'Small Menu Costs and large Business Cycles: a Macroeconomic Model of Monopoly". Quarterly Journal of Economics 100, 529-39.

Neumark, D. and S. Sharpe (1992): "Market Structure and the Nature of Price Rigidity: Evidence from the Market for Consumer Deposits", Quarterly Journal of Economics, 107, 657-680.

Nickell, S.J. and G. Quintini (2003): "Nominal Wage Rigidity and the Rate of Inflation", The Economic Journal 113, 762-781.

Salop S. C. (1979): "A Model of the Natural Rate of Unemployment", American Economic Review, 69, 117-125.

Shapiro, C. \& J. E. Stiglitz (1984): "Equilibrium Unemployment as a Worker Discipline Device", American Economic Review, 74, 433-44.

Smith, J.C. (2000). "Nominal Wage Rigidity in the United Kingdom," Economic Journal, $110,462,176-95$. 
Table 1. Determinants of Price Rigidity

\begin{tabular}{|c|c|c|c|c|}
\hline & $\begin{array}{c}\text { Price difference } \\
\text { between low \& high } \\
\text { demand condition }\end{array}$ & $\begin{array}{l}\text { Price in low demand } \\
\text { condition }\end{array}$ & $\begin{array}{c}\text { Price in high } \\
\text { demand condition }\end{array}$ & $\begin{array}{c}\text { Price in high and } \\
\text { low demand } \\
\text { condition }\end{array}$ \\
\hline Effort & $\begin{array}{c}-1.522 \\
{[0.649]^{\star *}}\end{array}$ & $\begin{array}{c}4.554 \\
{[0.205]^{\star * *}}\end{array}$ & $\begin{array}{c}2.407 \\
{[0.328]^{* \star *}}\end{array}$ & $\begin{array}{c}4.554 \\
{[0.201]^{\star \star \star}}\end{array}$ \\
\hline C treatment & $\begin{array}{c}13.368 \\
{[4.547]^{\star * *}}\end{array}$ & $\begin{array}{c}-17.895 \\
{[1.906]^{* * *}}\end{array}$ & $\begin{array}{c}11.341 \\
{[2.495]^{* * *}}\end{array}$ & $\begin{array}{c}-17.895 \\
{[1.870]^{* * *}}\end{array}$ \\
\hline ICR treatment & $\begin{array}{c}-9.717 \\
{[4.031]^{\star *}}\end{array}$ & $\begin{array}{c}0.412 \\
{[1.428]}\end{array}$ & $\begin{array}{c}-8.423 \\
{[2.656]^{* * *}}\end{array}$ & $\begin{array}{c}0.412 \\
{[1.400]}\end{array}$ \\
\hline High demand & & & & $\begin{array}{c}29.453 \\
{[3.168]^{\star \star *}}\end{array}$ \\
\hline Effort * High demand & & & & $\begin{array}{c}-2.147 \\
{[0.380]^{* * *}}\end{array}$ \\
\hline$C^{*}$ High demand & & & & $\begin{array}{c}29.235 \\
{[3.085]^{* \star *}}\end{array}$ \\
\hline ICR * High demand & & & & $\begin{array}{c}-8.835 \\
{[2.964]^{* * *}}\end{array}$ \\
\hline Constant & $\begin{array}{c}26.553 \\
{[4.567]^{* * *}}\end{array}$ & $\begin{array}{c}8.681 \\
{[1.449]^{* *}}\end{array}$ & $\begin{array}{c}38.134 \\
{[2.878]^{* * *}}\end{array}$ & $\begin{array}{c}8.681 \\
{[1.422]^{\star * *}} \\
\end{array}$ \\
\hline Observations & 27 & 1459 & 1561 & 3020 \\
\hline $\begin{array}{l}\text { R-squared } \\
\text { Clustered at session } \\
\text { level }\end{array}$ & $\begin{array}{c}0.54 \\
\text { no } \\
\end{array}$ & 0.61 & 0.64 & 0.74 \\
\hline
\end{tabular}

Note: Column (1) shows an OLS regression of price differences between the low- and high-demand conditions across the ICR, the ICF and the $\mathrm{C}$ treatment. The dependent variable is the mean price difference between the high-demand and low-demand conditions per effort level and treatment. Columns (2) and (3) show OLS regressions of prices in individual contracts on the $\mathrm{C}$ and the ICR treatments, with the ICF treatment as the omitted category. In the OLS regressions of column (4) individual prices in both the high and the low demand condition are the dependent variable and the ICF treatment in the low demand condition is the omitted category. Robust standard errors are in brackets in all regressions. ${ }^{* *}$ indicates significance at the $5 \%$ level, $* * *$ at the $1 \%$ level. 
Figure 1. Endogenous Reputation Formation in Markets

A. Reputation and Average Contract Efficiency over Time

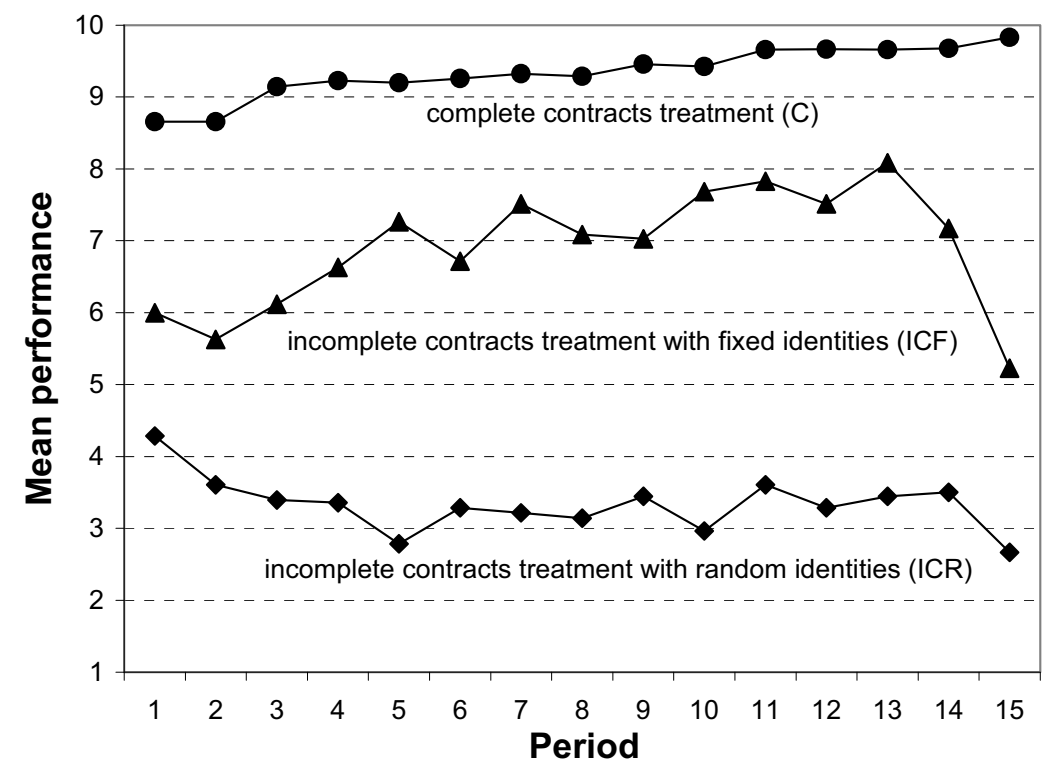

Note: In the ICF treatment, contracts are not third party enforceable and long-term relations (reputation building) are possible. Contracts in the ICR treatment are not third party enforceable, and long-term relations are ruled out. Contracts are third party enforceable and long-term relations are possible in the $\mathrm{C}$ treatment.

B. Performance of Selfish and Reciprocal Subjects in the Incomplete Contracts Treatment with Fixed Identities (ICF)

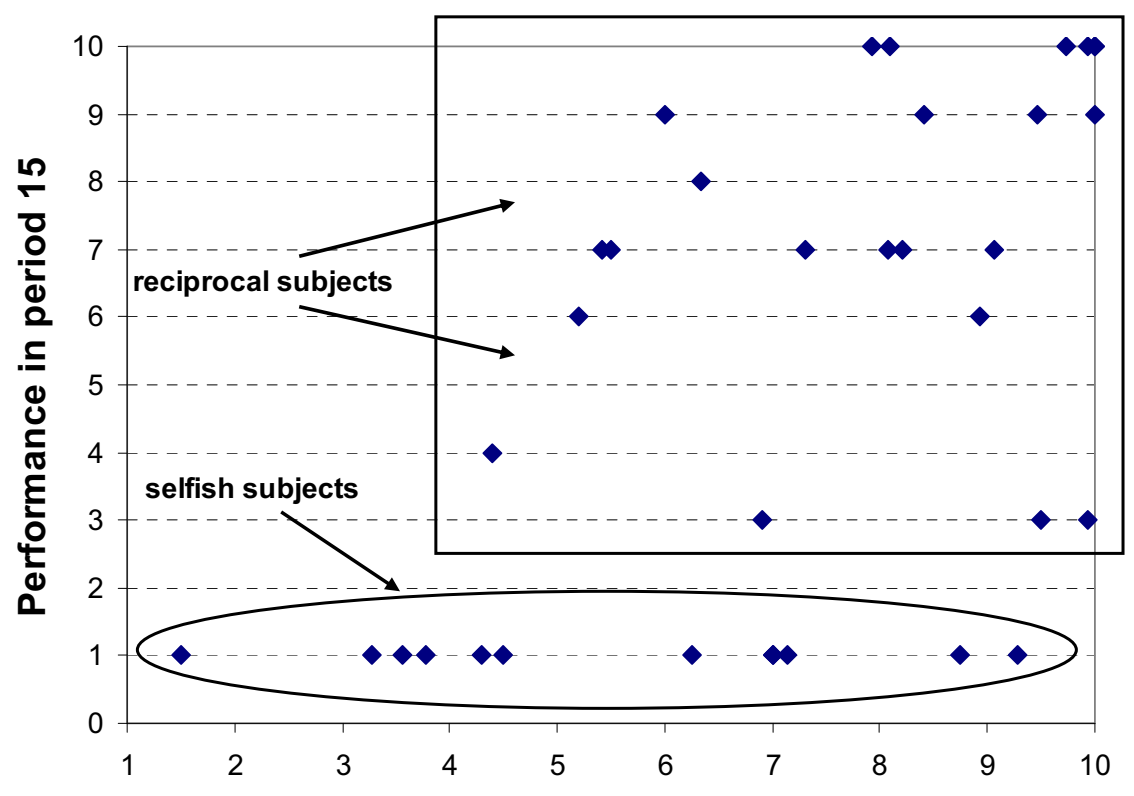

Mean performance in periods 1-14 


\section{Cumulative Share of Trades in Relationships of Various Lengths}

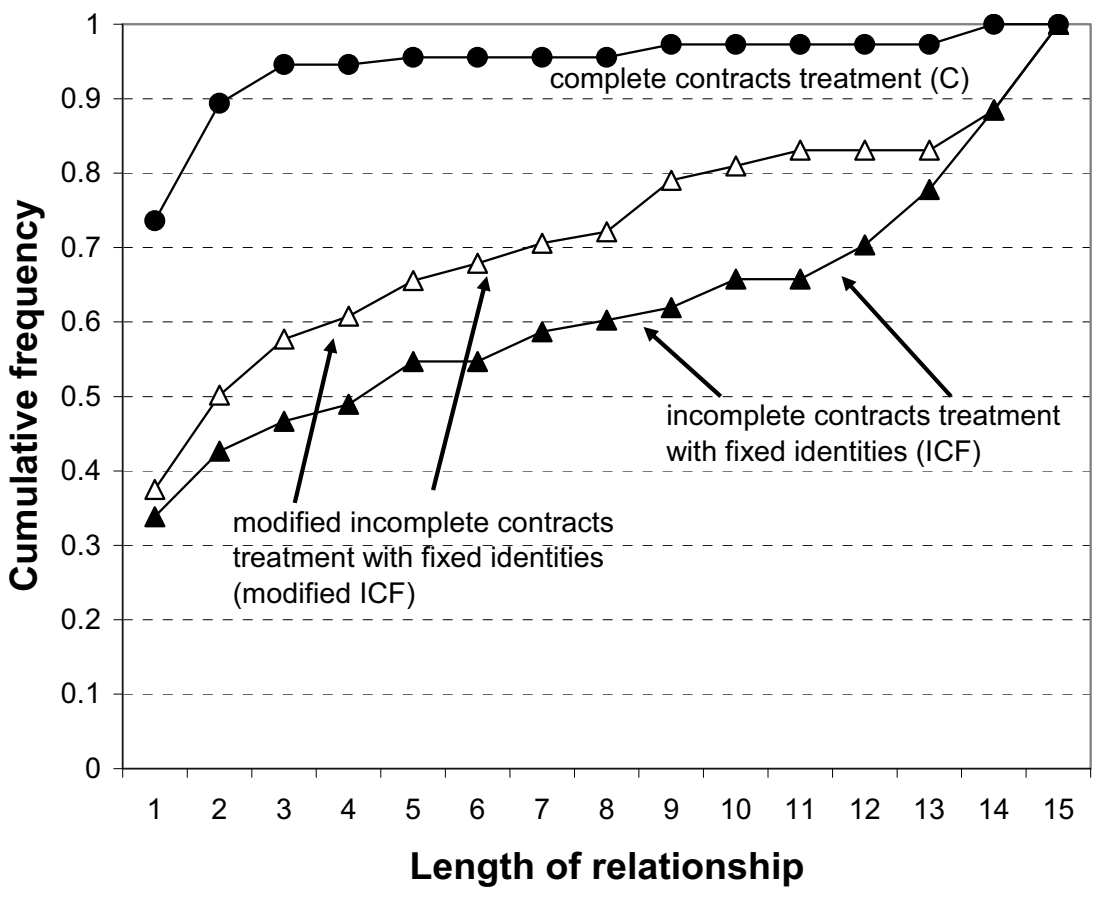

Note: In the ICF treatment, contracts are not third party enforceable and long-term relations (bilateral reputation) are possible. Contracts in the $\mathrm{C}$ treatment are third party enforceable and long-term relations (bilateral reputation) are possible. In the modified ICF treatment contracts are not third party enforceable and long-term relations as well as public reputation building is possible. 
Figure 2. Reputation and Reciprocity Effects on Performance under Excess

Demand and Supply

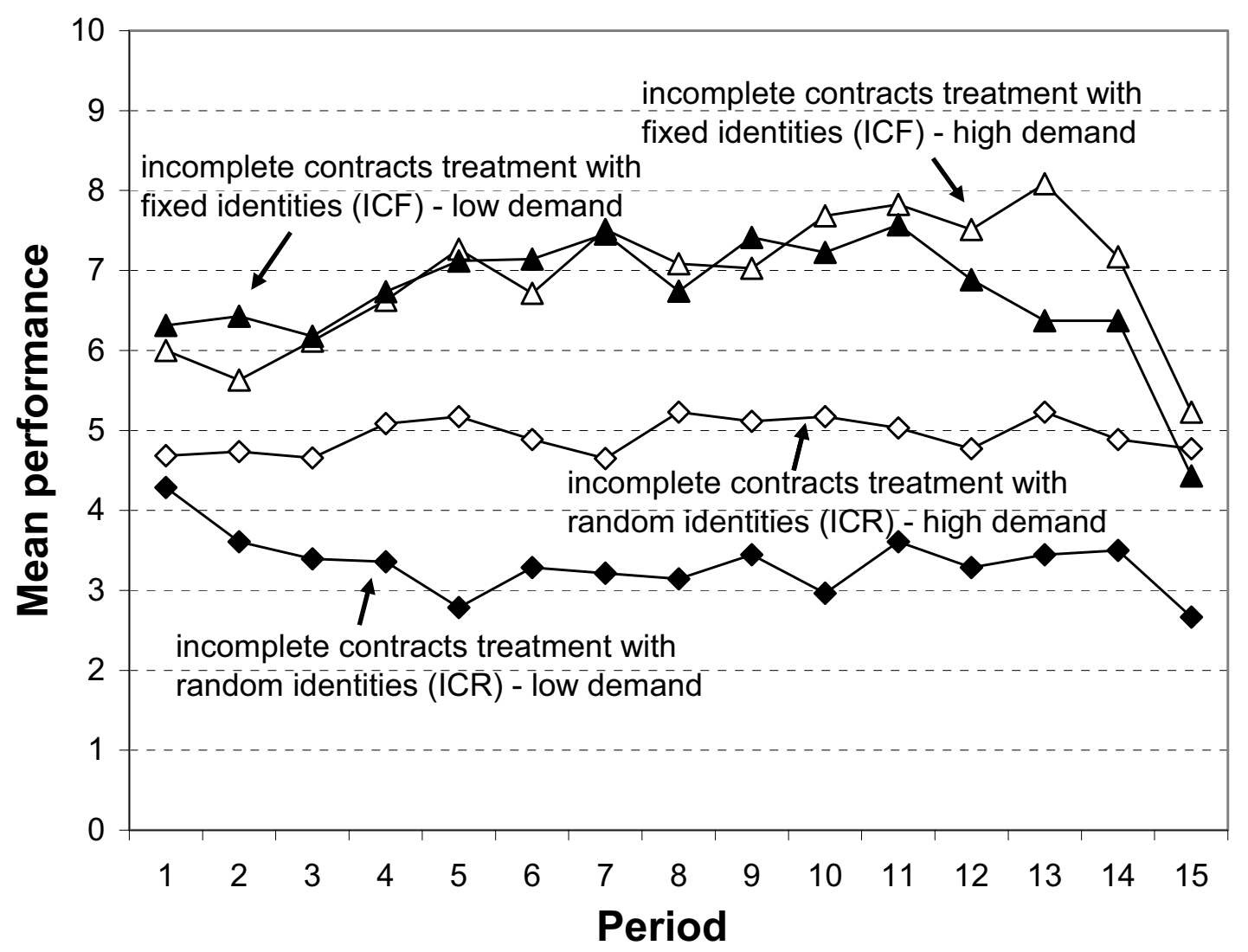

Note: "low demand" indicates excess supply of agents. "high demand" indicates excess demand for agents. Only reciprocity can enforce contracts in the ICR treatments. Both reciprocity and reputational incentives, as well as their interaction, can enforce contracts in the ICF treatments. 
Figure 3. Relational Contracts when Reciprocity fails

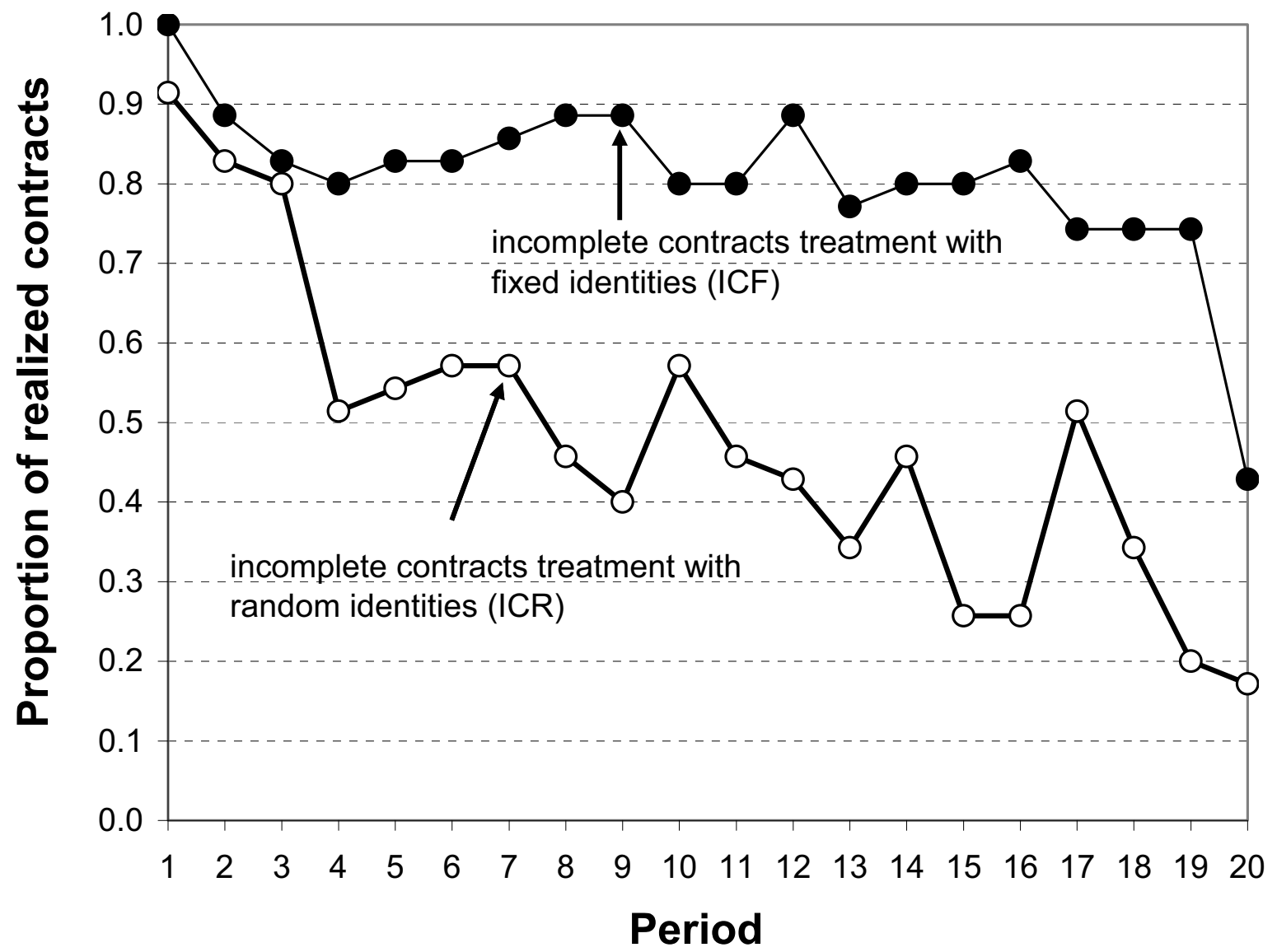

Note: Long-term relations between lenders and borrowers are possible in the ICF treatment, while long-term relations are ruled out in the ICR treatment. In both treatments, a lender faces the same two moral hazard problems: choice of inefficient high risk projects and lack of credit repayment in case of project success. 
Figure 4. The Impact of Reciprocity and Reputation on Price Rigidity

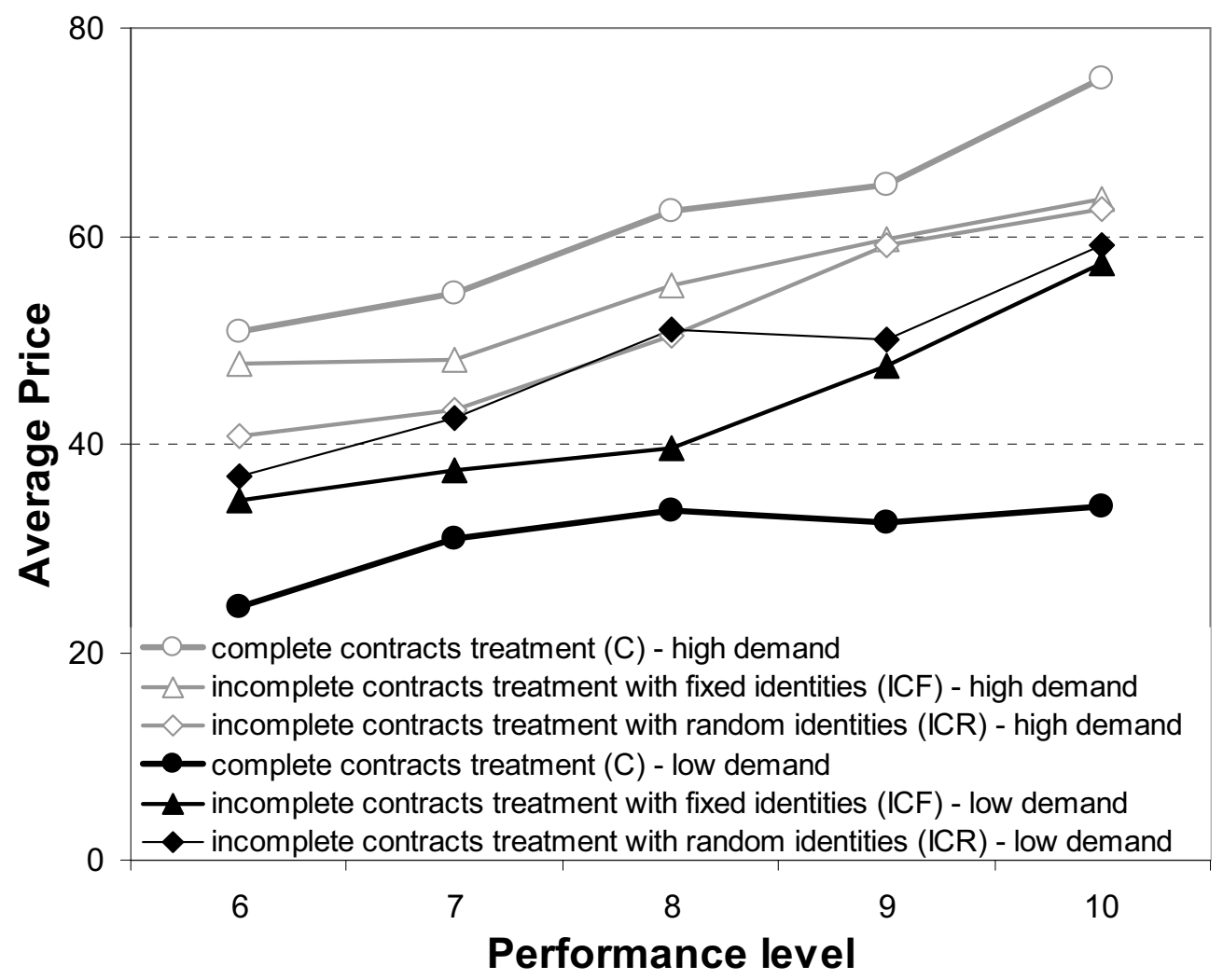

Note: "low demand" indicates excess supply of agents. "high demand" indicates excess demand for agents. Neither reciprocity nor reputation is needed for contract enforcement in the $\mathrm{C}$ treatments. In the ICR treatments, only reciprocity can enforce contracts. Both reciprocity and reputational incentives, as well as their interaction, can enforce contracts in the ICF treatments. 


\section{Swiss National Bank Working Papers published since 2004:}

2004-1 Samuel Reynard: Financial Market Participation and the Apparent Instability of Money Demand

2004-2 Urs W. Birchler and Diana Hancock: What Does the Yield on Subordinated Bank Debt Measure?

2005-1 Hasan Bakhshi, Hashmat Khan and Barbara Rudolf: The Phillips curve under state-dependent pricing

2005-2 Andreas M. Fischer: On the Inadequacy of Newswire Reports for Empirical Research on Foreign Exchange Interventions

2006-1 Andreas M. Fischer: Measuring Income Elasticity for Swiss Money Demand: What do the Cantons say about Financial Innovation?

2006-2 Charlotte Christiansen and Angelo Ranaldo: Realized Bond-Stock Correlation: Macroeconomic Announcement Effects

2006-3 Martin Brown and Christian Zehnder: Credit Reporting, Relationship Banking, and Loan Repayment

2006-4 Hansjörg Lehmann and Michael Manz: The Exposure of Swiss Banks to Macroeconomic Shocks - an Empirical Investigation

2006-5 Katrin Assenmacher-Wesche and Stefan Gerlach: Money Growth, Output Gaps and Inflation at Low and High Frequency: Spectral Estimates for Switzerland

2006-6 Marlene Amstad and Andreas M. Fischer: Time-Varying Pass-Through from Import Prices to Consumer Prices: Evidence from an Event Study with Real-Time Data

2006-7 Samuel Reynard: Money and the Great Disinflation

2006-8 Urs W. Birchler and Matteo Facchinetti: Can bank supervisors rely on market data? A critical assessment from a Swiss perspective

2006-9 Petra Gerlach-Kristen: A Two-Pillar Phillips Curve for Switzerland

2006-10 Kevin J. Fox and Mathias Zurlinden: On Understanding Sources of Growth and Output Gaps for Switzerland

2006-11 Angelo Ranaldo: Intraday Market Dynamics Around Public Information Arrivals

2007-1 Andreas M. Fischer, Gulzina Isakova and Ulan Termechikov: Do FX traders in Bishkek have similar perceptions to their London colleagues? Survey evidence of market practitioners' views 
2007-2 Ibrahim Chowdhury and Andreas Schabert: Federal Reserve Policy viewed through a Money Supply Lens

2007-3 Angelo Ranaldo: Segmentation and Time-of-Day Patterns in Foreign Exchange Markets

2007-4 Jürg M. Blum: Why `Basel II’ May Need a Leverage Ratio Restriction

2007-5 Samuel Reynard: Maintaining Low Inflation: Money, Interest Rates, and Policy Stance

2007-6 Rina Rosenblatt-Wisch: Loss Aversion in Aggregate Macroeconomic Time Series

2007-7 Martin Brown, Maria Rueda Maurer, Tamara Pak and Nurlanbek Tynaev: Banking Sector Reform and Interest Rates in Transition Economies: Bank-Level Evidence from Kyrgyzstan

2007-8 Hans-Jürg Büttler: An Orthogonal Polynomial Approach to Estimate the Term Structure of Interest Rates

2007-9 Raphael Auer: The Colonial Origins Of Comparative Development: Comment. A Solution to the Settler Mortality Debate

2007-10 Franziska Bignasca and Enzo Rossi: Applying the Hirose-Kamada filter to Swiss data: Output gap and exchange rate pass-through estimates

2007-11 Angelo Ranaldo and Enzo Rossi: The reaction of asset markets to Swiss National Bank communication

2007-12 Lukas Burkhard and Andreas M. Fischer: Communicating Policy Options at the Zero Bound

2007-13 Katrin Assenmacher-Wesche, Stefan Gerlach, and Toshitaka Sekine: Monetary Factors and Inflation in Japan

2007-14 Jean-Marc Natal and Nicolas Stoffels: Globalization, markups and the natural rate of interest

2007-15 Martin Brown, Tullio Jappelli and Marco Pagano: Information Sharing and Credit: Firm-Level Evidence from Transition Countries

2007-16 Andreas M. Fischer, Matthias Lutz and Manuel Wälti: Who Prices Locally? Survey Evidence of Swiss Exporters

2007-17 Angelo Ranaldo and Paul Söderlind: Safe Haven Currencies 
2008-1 Martin Brown and Christian Zehnder: The Emergence of Information Sharing in Credit Markets

2008-2 Yvan Lengwiler and Carlos Lenz: Intelligible Factors for the Yield Curve

2008-3 Katrin Assenmacher-Wesche and M. Hashem Pesaran: Forecasting the Swiss Economy Using VECX* Models: An Exercise in Forecast Combination Across Models and Observation Windows

2008-4 Maria Clara Rueda Maurer: Foreign bank entry, institutional development and credit access: firm-level evidence from 22 transition countries

2008-5 Marlene Amstad and Andreas M. Fischer: Are Weekly Inflation Forecasts Informative?

2008-6 Raphael Auer and Thomas Chaney: Cost Pass Through in a Competitive Model of Pricing-to-Market

2008-7 Martin Brown, Armin Falk and Ernst Fehr: Competition and Relational Contracts: The Role of Unemployment as a Disciplinary Device

2008-8 Raphael Auer: The Colonial and Geographic Origins of Comparative Development

2008-9 Andreas M. Fischer and Angelo Ranaldo: Does FOMC News Increase Global FX Trading?

2008-10 Charlotte Christiansen and Angelo Ranaldo: Extreme Coexceedances in New EU Member States' Stock Markets

2008-11 Barbara Rudolf and Mathias Zurlinden: Measuring capital stocks and capital services in Switzerland

2008-12 Philip Sauré: How to Use Industrial Policy to Sustain Trade Agreements

2008-13 Thomas Bolli and Mathias Zurlinden: Measuring growth of labour quality and the quality-adjusted unemployment rate in Switzerland

2008-14 Samuel Reynard: What Drives the Swiss Franc?

2008-15 Daniel Kaufmann: Price-Setting Behaviour in Switzerland - Evidence from CPI Micro Data

2008-16 Katrin Assenmacher-Wesche and Stefan Gerlach: Financial Structure and the Impact of Monetary Policy on Asset Prices

2008-17 Ernst Fehr, Martin Brown and Christian Zehnder: On Reputation: A Microfoundation of Contract Enforcement and Price Rigidity 
Swiss National Bank Working Papers are also available at www.snb.ch, section Publications/Research Subscriptions or individual issues can be ordered at Swiss National Bank, Fraumünsterstrasse 8, CH-8022 Zurich, fax+41 4463181 14, E-mail library@snb.ch 